\title{
Modelling Estimation of the Available Rainwater Resource in Gbédji-Kotovi Clay Area for Supplying Dikes and Dams
}

\author{
Kassa Issifou Mounou Sambieni, François de Paule Codo \\ National Water Institute (INE), University of Abomey-Calavi, Cotonou, Benin \\ Email: kssiff@yahoo.fr
}

How to cite this paper: Sambieni, K.I.M. and de Paule Codo, F. (2020) Modelling Estimation of the Available Rainwater Resource in Gbédji-Kotovi Clay Area for Supplying Dikes and Dams. Open Journal of Modern Hydrology, 10, 30-43.

https://doi.org/10.4236/ojmh.2020.102003

Received: February 21, 2020

Accepted: April 26, 2020

Published: April 29, 2020

Copyright $\odot 2020$ by author(s) and Scientific Research Publishing Inc. This work is licensed under the Creative Commons Attribution International License (CC BY 4.0).

http://creativecommons.org/licenses/by/4.0/

\begin{abstract}
Floods and flows data are useful for dimensioning of dikes and dams which often include evacuation devices that regulate flows to ensure the volumes of water. The objective of this study is to estimate the available water resource in the village of Gbédji-Kotovi, located in the watershed of Couffo river in Benin by using sequentially, the HBV (Hydrologiska Byråns Vattenbalansavdelning) and GR4J (Rural Engineering model with 4 daily parameters) climate models. Hydrographs of water levels are simulated according to the calibration period (1994-1999) different from the validation one (1982-1988). Considering the Nash-Sutcliffe model Efficiency coefficient (NSE), the performance of GR4J model during calibration is slightly higher than the performance of the HBV model, while during the validation, the contrary is noticed. The annual rainfall average simulated is $1117.7 \mathrm{~mm}$ /year while the average observed is 1104.6 $\mathrm{mm}$ /year over the period 1981-2005. By 2050, on one hand, the annual flow rate values will vary from -19.2 to $-11.9 \%$, while the actual evapotranspiration will vary between 0.5 and -5.8 ; on another hand, the potential evapotranspiration and the annual precipitation remain constant. An average flow of 187 millions $\mathrm{m}^{3} /$ year for annual average water depth of $1094 \mathrm{~mm}$ is obtained at Lanta rain station, which covers an area of $1664.47 \mathrm{~km}^{2}$, while this flow enabled an average flow of 327.5 millons $\mathrm{m}^{3} / y e a r$ to be obtained at the virtual station of our study area of $2908.15 \mathrm{~km}^{2}$. The flow rates corresponding to the return periods of 10,25 and 50 years vary from 5.51 to $12.67 \mathrm{~m}^{3} / \mathrm{s}$ at the outlet of the virtual station; while those at the outlet of Lanta station vary from 3.6 to 6.6 $\mathrm{m}^{3} / \mathrm{s}$. However, the simulated water quantiles cannot be fully mobilized; because of the uses, they undergo upstream and downstream. Thus, Gbédji-Kotovi locality requires the implementation of an integrated water resource management strategy that includes the construction of dikes and dams.
\end{abstract}




\section{Keywords}

Rainwater, Modelling, Couffo Watershed, Gbédji-Kotovi, Dikes and Dams

\section{Introduction}

The volume of watershed or the bowl of stream determines the design of a dam or a dike's. Indeed, design and operation of a dam require having adequate volume of water and volume flow for the determination of its key parameters and to ensure its stability [1].

In hydrology and hydraulics, one of the main goals is transforming rainfall into flowrate, which has led to the development of a lot of models, with their own conditions of application and with current and future changes which have influence on hydrological regimes of watersheds. This study aims to estimate with a model, the rainwater resource by supplying dikes and dams in Gbedji-Kotovi. The interest of the construction of dikes and dams on Couffo watershed, particularly in this area, a clay zone is the transition that will be created from extensive and seasonal agriculture to intensive agriculture which appears as one of the solutions to maintain the agricultural production potentiality to minimize ecological consequences.

On one side, the clay soil of Gbédji-Kotovi village in Couffo watershed gets certain hydro-mechanical and physico-chemical characteristics favouring the construction of dikes and earth dams [2] [3]. Those clays are mainly the smectites with compact and fused textures [4] [5]. This mineralogy gives them low and medium permeabilities that change, according to the depth, the topography of the site and its geological and environmental conditions. In those previous studies, the used methods made only possible to evaluate the terms of the water balance at the scale of the plot, and the experiments provide only partial results, concerning only the part of the watershed, according to the localized information on the genesis of flows.

On another side, regarding the inputs from the Couffo River watershed, the present and future parameters can be taken into account in this study by conceptual and simple global models [6]. Authors tested several models including the GR4J and HBV models on the Mekrou Basin at the outlet of Kompongou (Benin). Calibrating the two models, they present the best Nash criteria $(0.83$ and 0.82 ) by considering the whole basin because the physical processes are still poorly known in this area.

The objective of this paper is to determine first, the flowrate of flood or low water quantity from climate parameters and then to know how often these flow rates may occur, in order to supply eventually dikes and dams. Based on the conditions expressed from the observations, hydrological forecast is simulated, taking into account weather forecasts, expressed with the precipitation and the temperature. 
Finally, it establishes a water balance and a prediction of future volumes and flows in a site without a hydrological station, but located at the outlet of the upstream known rainfall station at Lanta.

It confirms the possibility of estimating the quantities of rainwater for many watersheds without hydrological stations (and especially located in rural areas), in general, and also constitutes a decision aid tool in construction of dikes and dams.

The results of this study will constitute a decision-making aid tool for the construction of dikes and dams in this locality in the context of climate change.

\section{Study Area}

Gbédji-Kotovi clayey zone is located in the Couffo River watershed in Benin (Figure 1). The hydrographic network of the Couffo watershed is a dendritic type, as well as a variable flow (semi-navigable, permanent, semi-permanent and seasonal or temporary. Its long profile has an exponential appearance, with slopes rising from $10 \mathrm{~m} / \mathrm{km}$ at the head of the basin to $0.3 \mathrm{~m} / \mathrm{km}$ upstream from Lake Ahémé [7]. This basin extends over a length of $190 \mathrm{~km}$ and has its source in Togo at $240 \mathrm{~m}$ above the sea level, near Tchetti village. It flows into Lake Ahémé, $24 \mathrm{~km}$ long and whose outlet is the complex lagoon "Bouches du Roi". The rivers constituting the tributaries are for minor importance and have high slopes (5 to 13 $\mathrm{m} / \mathrm{km}$ ). On the Cretaceous and Eocene formations, the fluvial system is nonexistent [8]. The reference rain station at Lanta is between $07^{\circ} 06^{\prime} 43^{\prime \prime} \mathrm{N}$ latitude and $01^{\circ} 52^{\prime} 43^{\prime \prime} \mathrm{E}$ for longitude, and is approximately $65 \mathrm{~m}$ above sea level zero point.

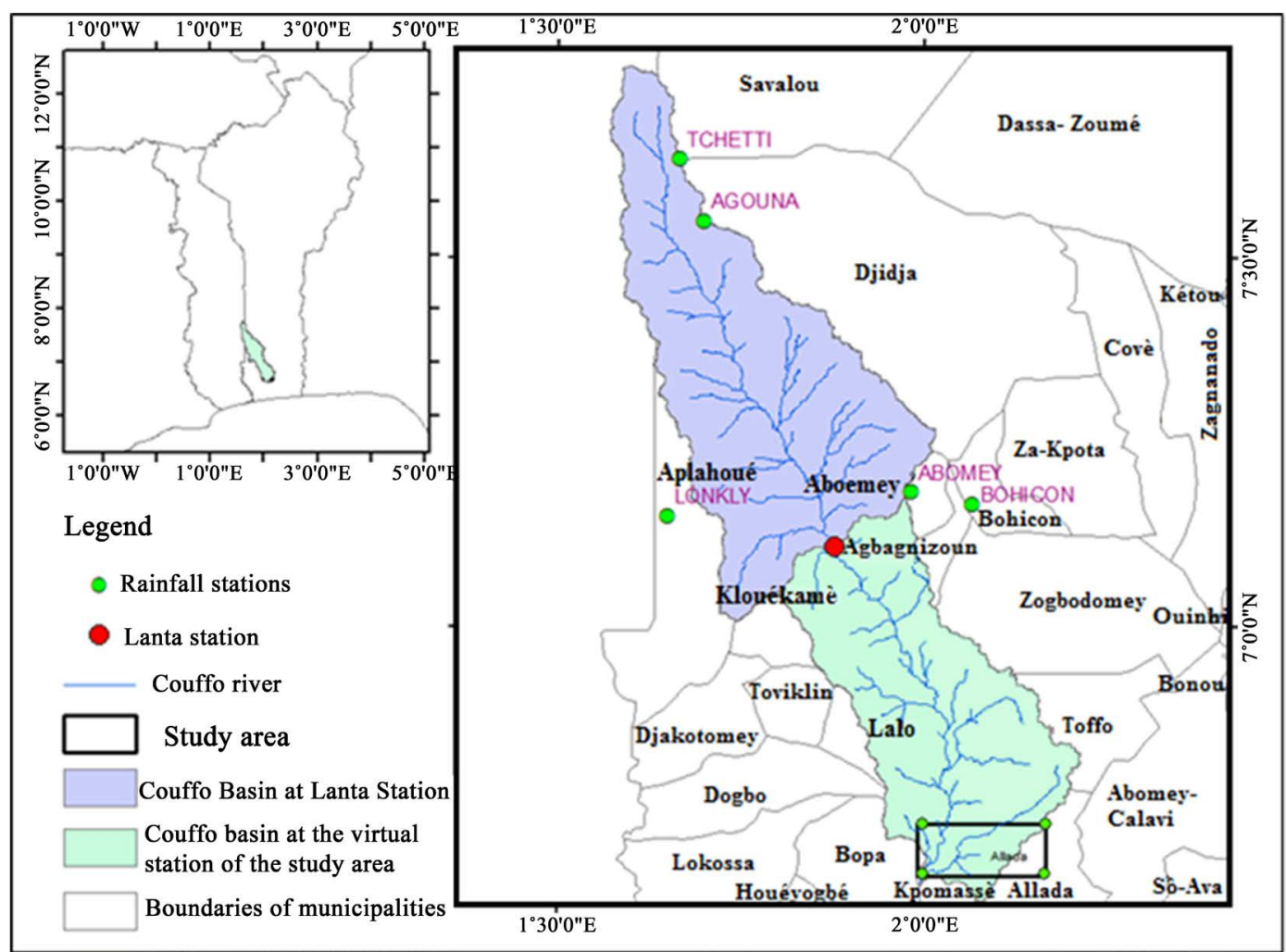

Figure 1. Couffo Basin showing the virtual basin considered, at the upstream outlet of Lanta station. 
It covers an area of $1680 \mathrm{~km}^{2}$. The Couffo watershed has a natural regime at Lanta area and the rivers from the main hydrographic network are dominated by relatively homogeneous vertisols with significant vegetation [9].

\section{Materials and Methods}

\subsection{Data of Study}

Due to lack of hydrological or rainfall station in the area of the Gbédji-Kotovi clay complex, we have extended the obtained flow at the Lanta station to a virtual station located about $15 \mathrm{~km}$ from the upstream of the Lanta station. The two stations (the vitual station and station of Lanta) are located in the watershed of Couffo River.

Then we considered two simple models for application to the Couffo basin (Figure 2), which are HBV [10] and GR4J [11]. The climatic data used in this study were acquired at the Agency for the Safety of Air Navigation in Africa and Madagascar (ASECNA) in Cotonou. The monthly flow data of Couffo in Lanta is obtained from the General Direction for Water (DG Eau) in Benin.

\subsection{GR4J Model}

GR4J is a global conceptual model of Rural Engineering, with 4 daily parameters. It is in the form of an Excel spreadsheet and simulates daily flow rate values from $\mathrm{P}$ basin average rainfall data $(\mathrm{mm})$, potential ETP evapo-transpiration $(\mathrm{mm})$ and $\mathrm{Q}$ flows $\left(\mathrm{m}^{3} / \mathrm{s}\right)$. This model has two reservoirs regulated by four parameters to optimize to better approximate value, the transformation of rain into flow. It includes unit of hydrographs and a water exchange function to regulate exchanges with the outside of the basin: 1) a production reservoir that governs the production function (soil tank S); 2) a routing tank governing the transfer function (routing tank R). The hydrological modelling methodology on the basin is explained by the display of the operating diagram of the GR4J model. This model can be executed in Microsoft Excel (Figure 2(a)). The four parameters of the model to optimize in calibration are: 1) X1: capacity of the production tank (mm); 2) X2: underground trade coefficient (mm); 3) X3: one-day capacity of the routing tank (mm); 4) X4: basic time of unit hydrogram HU1 (days).

\subsection{HBV Model}

It is a global conceptual model at the catchment scale, which is able to calculate different flows for various mechanisms [12]. This computer model converts, by simulating natural hydrological processes, precipitation data, potential evaporation, and (where applicable) snowmelt into values of river flow and/or reservoir inflow (Figure 2(b)). Despite its robustness and relative simplicity, it integrates topographical features such as area and altitude for the spatial discretization of the study area in homogeneous zones, modules for calculating soil moisture, infiltration to the aquifer underground as well as the transfer function. But to simplify 
(a)

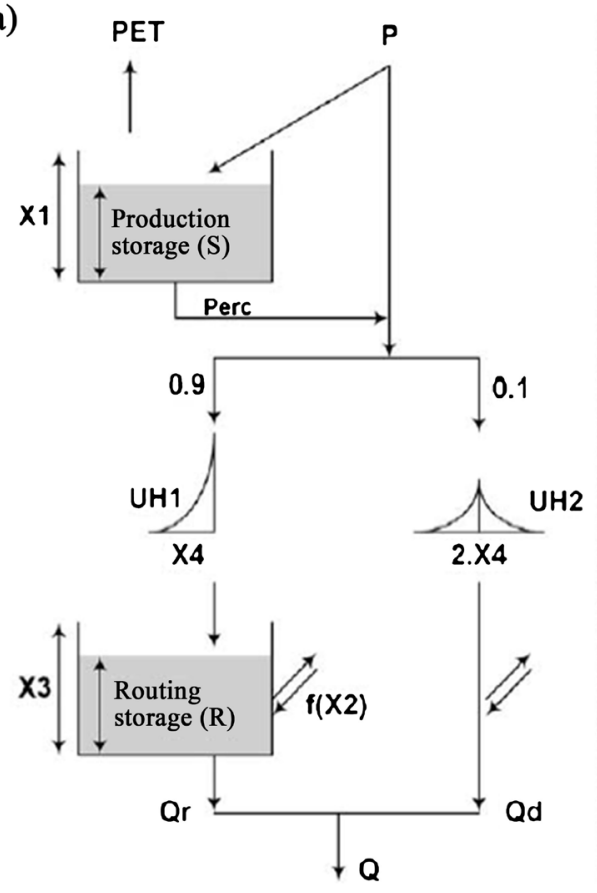

(b)
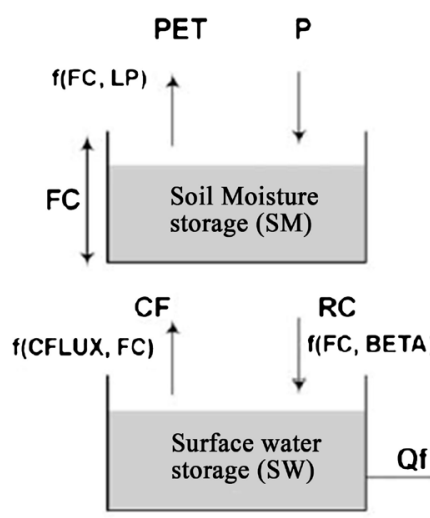

$\rightarrow f(K F, A L F A)$

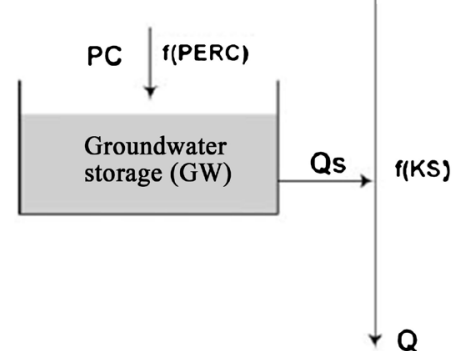

Figure 2. Paterns of (a) GR4J model [12] and (b) HBV model [13].

it further, some components can be rendered inactive. The HBV model and its variants have been applied in a large number of countries and environments [13]. In fact, the model includes sub-programs for snow accumulation and melt, for calculating soil moisture, for groundwater, and a procedure for calculating flood propagation. It uses eight (08) parameters that control: 1) melting and accumulation of snow, 2) ground cover interception, 3) direct runoff, 4) ground tank, 5) the correction of evapo-transpiration, 6) the emptying of underground reservoirs, 7) transfer at sub-basin level (MAXBAS) to the river node, and 8) transfer to the river system. Those parameters can be classified into two categories: a) production parameters that affect the water balance, and b) transfer parameters that affect the shape of the output hydrograph.

Depending on the production function for the vertical flow of this model, the recharge of the water table and the actual evapo-transpiration are functions of the current water storage in the soil tank. The surface flow takes place through three reservoirs, the first of which is non-linear. Thus the model is semi-distributed while the parameters of the transfer function are global by sub-basin. Standard HBV calculates this propagation by combining, for example, the Muskingum method with a complementary function of phase shift. The observations of the propagation in the basins are made by the trap method. For the regulation of floods, one can take into account strategies of exploitation of the water reservoirs in the very complex systems of reservoirs. The most important parameters are estimated by carrying out a calibration which, in general, requires 3 to 5 years of 
simultaneous recordings of river flow and weather conditions. In the absence of river flow records, the parameters can in some cases be estimated based on the known characteristics of the basin. In the rest of this article, we used the simple version of HBV, called HBV light. The runoff rate (Qs) is calculated based on the average input precipitation $(\mathrm{Pe})$, a certain direct runoff threshold or vegetation parameter, and a runoff coefficient.

To go from the column of soil to the slope, we superimposed the slow flows and fast flows. These flows were then transformed by a triangular filter (parameter of the MAXBAS unit hydrograph). The propagation of the node from a slope upstream to the slope downstream is done by the modified Muskingum method.

With only daily rainfall, hourly rain is obtained assuming a uniform distribution over the day. Thus, the time of computation of the model is hourly but the results are evaluated in the step of time daily.

\section{Quality Criteria}

The model is validated by comparing the flows calculated and observed through a quality criterion. The best-known and most widely used criterion for conceptual models is the Nash and Sutcliff (1970) criterion, which is expressed by the equation below:

$$
\operatorname{Nash}(Q)=100\left[1-\frac{\sum_{i}\left(Q_{i, o b s}-Q_{i, c a l}\right)^{2}}{\sum_{i}\left(Q_{i, o b s}-Q_{o b s}\right)^{2}}\right]
$$

To account for some particular flow rates, this criterion was calculated using the square root of flows to mitigate the importance of peak flows, or the logarithm of low flow rates.

In practice, the simulation is considered to be of poor quality when the Nash criterion is less than $70 \%$. It is acceptable when this criterion is greater than $70 \%$ and perfect if it is equal to $100 \%$.

\section{Calibration and Validation}

The calibration of the two above-mentioned models consisted, after starting them, of changing their parameters so that the simulated flow rates are superimposed as closely as possible on the flows observed while ensuring the hydrological balance. Performance criteria such as Nash (NSE) and percent bias (PBias) were used. The NSE can vary from $[-\infty, 1]$. The estimate is better when this value approaches the number 1. The PBias, with its optimal value of zero can be both positive and negative. Validation was carried out over a period (1982-1988) different from that of calibration (1994-1999). But the parameters of the model obtained at calibration have remained unchanged.

To assess the availability of the resource in 2050, we considered the Hadley Centre Global Environment Model version 2 (HadGEM2-ES) climate model [14], based on the Cordex Africa experiment of the International Center for Theoretical 
Physics (ICTP). We first performed a data correction using the method of Quantile mapping temperature and precipitation data [15]. The reference period considered is 1981-2005 and that of future projections is 2005-2050. Then, the corrected data were used to force the two hydrological models previously calibrated and validated to estimate the future availability of the water resource. The quantile mapping method has been used to reduce the error on the rainfall estimates for the Lanta station Basin.

The considered calibration period is from 1994 to 1999 and the validation period, from 1982 to 1988 . During these two different periods, the performances of the models were satisfactory (Table 1). Considering the value of the NSE, the performances of the GR4J model are slightly better than those of the HBV model during the calibration. On the other hand, during validation, the performances of the HBV model are superior to those of the GR4J model. We did not observe a big difference between the annual flows and volumes simulated and those observed.

The rainfall correlation obtained for the two models is very satisfactory. On one hand, the maxima are observed for the periods 1987-1988, 1999-2000 and 2007-2008. On the other hand, the minima are indicated for the years 1983, 1986; from 1992 to 1998 and from 2001 to 2005 (Figure 3).

On the hydrographs of the observed and simulated data (Figure 4) we see that both during calibration and during validation, the high and low water levels are

Table 1. Performance of calibration and validation models.

\begin{tabular}{ccccccc}
\hline & \multicolumn{3}{c}{ Calibration } & \multicolumn{3}{c}{ Validation } \\
\cline { 2 - 7 } Model & GR4J & HBV & Obs & GR4J & HBV & Obs \\
\hline NSE & 0.61 & 0.57 & & 0.55 & 0.59 & - \\
PBias (\%) & -3.12 & 5.04 & & 3.16 & 19.55 & - \\
Annual flows (mm/year) & 116.73 & 126.57 & 120.49 & 73.53 & 85.42 & 71.28 \\
Annual Volume (million m m $^{3}$ year) & 196.11 & 212.64 & 202.43 & 123.54 & 143.50 & 119.75 \\
\hline
\end{tabular}

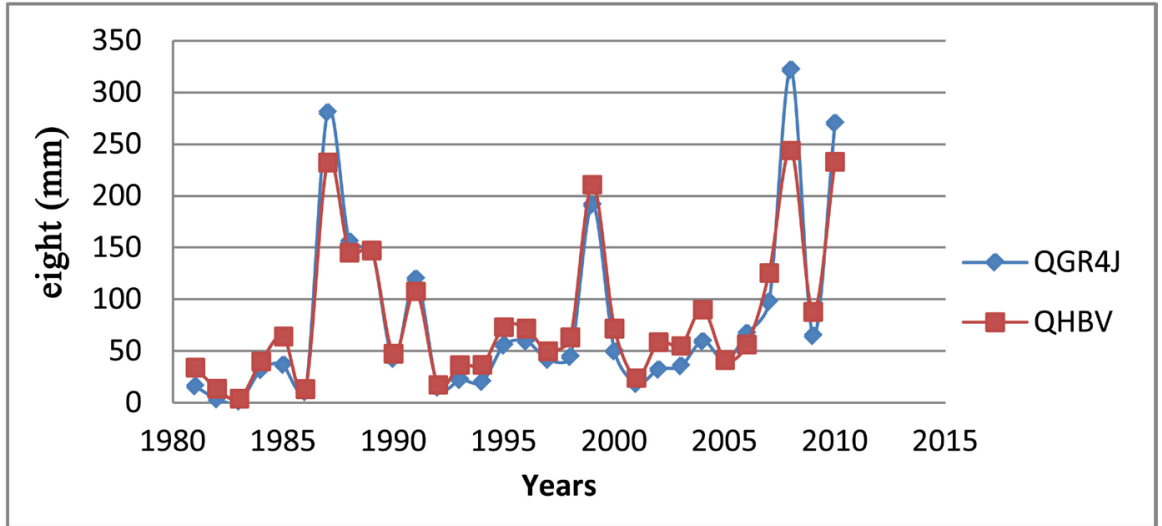

Figure 3. Maxima and minimum rainfall heights by GR4J and HBV models. 

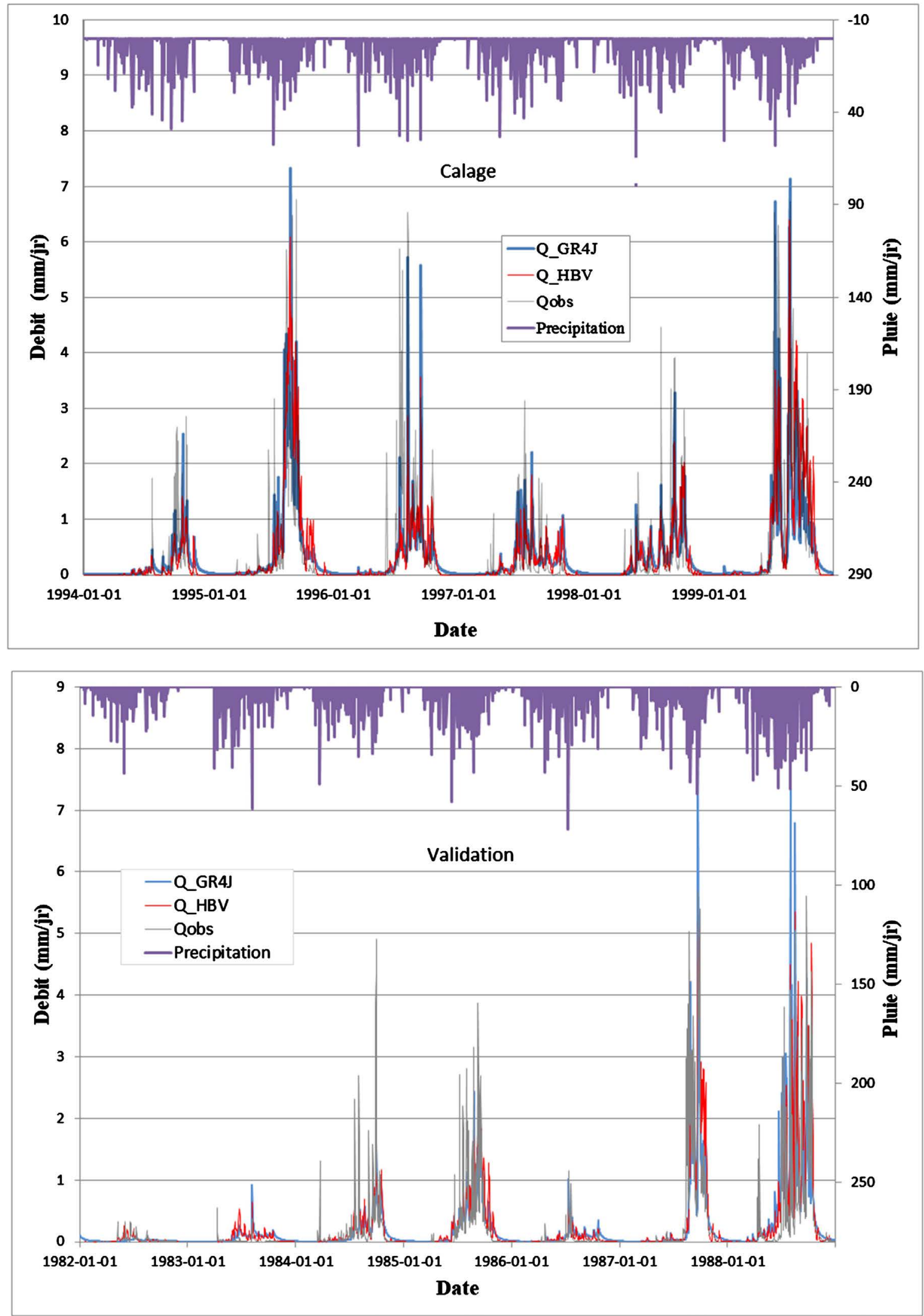

Figure 4. Hydrograph from calibration and validation of HBV and GR4J models in the Couffo basin at the Lanta outlet. 
well simulated. We also note a pronounced drought (which tends towards rupture) in the years 1983 and 1987. So, we can say that the HBV and GR4J models thus reproduce the variation regimes of the Couffo basin at the Lanta station. In view of these results, these two hydrological models can be used for an impact study.

Figure 4 shows the hydrographs observed and simulated both for the calibration period and for the validation period. We can observe on this figure, that the high waters as well as the low waters are well simulated. The HBV and GR4J models acceptably reproduce the variation regimes of the Couffo basin watercourse at Lanta station. In view of all these results, the two hydrological models HBV and GR4J can be used for an impact study. We performed a data correction using the Quantile mapping method [15] of temperature and precipitation data. The reference period considered is 1981-2005 and that of future projections is 2005-2050. Then, the corrected data were used to force the two hydrological models previously calibrated and validated to estimate the future availability of the water resource.

\section{Results and Discussion}

\subsection{Availability of Water Resources by 2050 in the Couffo Basin at the Outlet of Lanta}

From Table 1 indicating the criteria used for calibration and validation, we can get an idea of the current availability of the resource available at Lanta station. It ranges from 119 million $\mathrm{m}^{3}$ to 202 million $\mathrm{m}^{3}$ per year, or between 3.80 and 6.40 $\mathrm{m}^{3} / \mathrm{s}$. These results are similar to those obtained by [16], which are between 3.6 and $6.6 \mathrm{~m}^{3} / \mathrm{s}$.

The quantile mapping method significantly reduced the error on the Lanta basin rainfall estimates as shown in Figure 5 below.

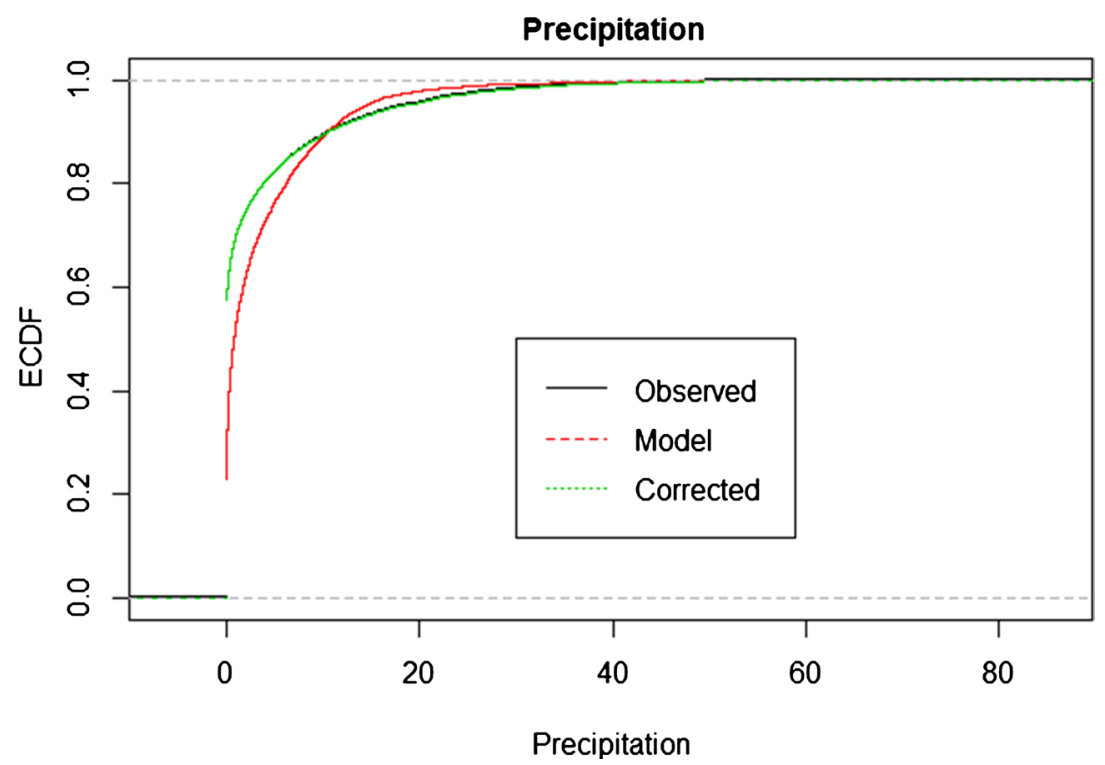

Figure 5. Correction curve of data from the HadGEM2-ES climate model. 
This figure represents the cumulative density function of the data after its forcing, by using the HadGEM2-ES model. Thus, we noted the function of the uncorrected model data (red curve), the function for after the correction by the HadGEM2-ES model (green curve), and the function of the data observed or provided by the meteorological services (black curve confused with the green curve). One remarks a perfect superposition of the two curves from observations (green curve) and simulations (black curve) after correction with HadGEM2-ES model, indicating a very appropriate correction of the data by this model.

The annual average of the results obtained after correction of the data from the HadGEM2-ES climate model is $1117.7 \mathrm{~mm}$ /year while that corresponding to the observations is $1104.6 \mathrm{~mm} /$ year over the period 1981-2005. By 2050 (2005-2050), the rain will decrease slightly according to the same climate model, amounting to an average of $1094 \mathrm{~mm}$ /year. In the same way, the temperature data have been corrected by the same method and they will increase significantly.

Table 2 presents the results of the hydrological two models, with climatic data corrected from the HadGEM2-ES climate method. The different components of the hydrological balance will decrease by 2050 . The flows decrease between $11.9 \%$ according to the GR4J model and $19.2 \%$ according to the HBV model. The gross resource available by 2050 could reach an average of 187 million cubic meters per year.

Considering the elongated shape of the basin, we have first approximated the available resource at the virtual outlet (study area) by a simple rule of correspondence between area and available volume. The size of the virtual basin is $2908.15 \mathrm{~km}^{2}$ and that of Basin in Lanta is $1664.47 \mathrm{~km}^{2}$ ). Thus, the volume of water at the virtual station will be approximately [( 187 million cubic meters per year) $\times 2908.15 / 1664.47$ ] or 327.5 million cubic meters per year or 10.37 cubic meters per second on average horizon 2050. However, it should be noted that this entire volume cannot be fully mobilized because of other users upstream and downstream. As a result, integrated management of water resources in the basin needs to be considered according to the current annual volume of 187 million cubic meters of surface water available at the outlet of the Couffo watershed which is an integral part of Benin's surface water resource of 13.88 billion cubic meters [17].

Table 2. Components of the water balance taking into account climate scenario RCP8.5 of the HadGEM2-ES climate model.

\begin{tabular}{|c|c|c|c|c|c|c|}
\hline \multirow{2}{*}{ Components } & \multicolumn{3}{|c|}{ HBV } & \multicolumn{3}{|c|}{ GR4J } \\
\hline & $1981-2005$ & $2006-2050$ & Variation (\%) & $2006-2050$ & $1981-2005$ & Variation (\%) \\
\hline Flow rate $\mathrm{Qsim}\left(10^{6} \mathrm{~m}^{3} /\right.$ year $)$ & 143.7 & 116.2 & -19.2 & 123.8 & 109.1 & -11.9 \\
\hline Precipitation/year & 1117.7 & 1094.5 & -2.1 & 1117.7 & 1094.5 & -2.1 \\
\hline Actual Evapotranspiration (AET) & 974.5 & 979.2 & 0.5 & 882.9 & 831.9 & -5.8 \\
\hline Potential Evapotranspiration (PET) & 1475.7 & 1475.7 & 0.0 & 1475.7 & 1475.7 & 0.0 \\
\hline
\end{tabular}




\subsection{Determination of Return Flows from the Allada Virtual Station in the Couffo Watershed}

In order to determine return period flows, in order to optimize the sizing choices of the dams and dikes, an estimation of the flow rates was made at Allada virtual station. Thus, we carried out a spatialization of the rain on the whole basin at the considered outlet of the station of Lanta, from 1981 to 2010. The parameters of models HBV and GR4J previously obtained were considered as proxy to simulate the flows at the virtual station of Allada. The sampling method used for frequency analysis is annual maxima. The general law of extreme values (GEV) is the distribution used. Table 3 shows the quantiles corresponding to the different return periods. There is a big difference between the results from the two models. The advantage of the multi-modelling in this work is to be able to compare the results and to deduce the uncertainties which increase with the return period as indicated in Table 3.

The flows of approximately $5.51 \mathrm{~m}^{3} / \mathrm{s}, 8.99 \mathrm{~m}^{3} / \mathrm{s}$ and $12.67 \mathrm{~m}^{3} / \mathrm{s}$ correspond respectively to the return periods of 10 years, 25 years and 50 years on the Couffo basin at the exit of the virtual basin considered. However, the uncertainty is greater from a period of 50 years because of the length of the data used. Those changes in the overall availability of water resources in the Couffo watershed may be the consequence of the dynamics of surface states on one hand, and the translation of climate changes and variability on other hand. They can also be related to the distance of the validation period compared to the calibration period. Thus, one can note a degradation especially in the reproduction of the flood flows, confirming the instability of the parameters of the models in the time. Because of these uncertainties over the stability of the parameters over time, it would be difficult to predict the flood flows with the models used, especially on distant horizons to evaluate, for example, the impacts of climate change.

The global analysis of the obtained results indicates strong interannual fluctuations of precipitation in wet periods and in dry periods, with a downward trend, and highlights three phases: a very humid phase, a dry phase and a wet phase.

Table 3. Quantiles corresponding to the different return periods obtained from the flows simulated by the two models in million $\mathrm{m}^{3} /$ year then the parameters of the GEV model.

\begin{tabular}{|c|c|c|c|c|c|c|c|c|}
\hline \multirow{2}{*}{ Quantiles } & \multicolumn{3}{|c|}{ Return Periods (years) } & \multicolumn{5}{|c|}{ Parameter Value (GEV) } \\
\hline & 10 & 25 & 50 & & & Location & Scale & Shape \\
\hline \multirow[t]{2}{*}{ GR4J } & 177 & 315 & 474 & & Value & 47.4 & 37.8 & 0.3 \\
\hline & & & & GR4J & & & & \\
\hline $\mathrm{HBV}$ & 170 & 254 & 333 & & Type deviation & 8.0 & 6.8 & 0.2 \\
\hline \multirow[t]{2}{*}{ Average } & 174 & 284 & 404 & & Value & 33.5 & 32.5 & 0.5 \\
\hline & & & & $\mathrm{HBV}$ & & & & \\
\hline Type deviation & 3 & 30 & 70 & & Type deviation & 6.9 & 6.8 & 0.2 \\
\hline
\end{tabular}


Those results corroborate with those obtained by [17] in Benin and those obtained by [18] in West Africa. This climatic deterioration associated with the degradation of natural formations in favour of anthropogenic formations leads to a weakening of the vegetal cover and a degradation of the grounds which causes the loss of fertility in the agricultural lands [19]. According to these authors, the degradation of rainfall, associated with environmental problems including the degradation of vegetation cover, water erosion, land pollution is at the base of the decline in agricultural yields, very marked differences between planted area and agricultural production. The results are consistent with those of [20] [21] [22] [23] according to which the decrease in crop yields is attributed to climate change and high pressure on agricultural land, which leads to food insecurity.

Furthermore, to make better use of the surface water availability provided by the two models GR4J and HBV, the construction of water reservoirs (dikes or dams) intended to promote agro-pastoral and industrial activities is necessary in the area of Gbedji-Kotovi. This surface water recovery option corroborates with that proposed by [24] for the Klou watershed.

\section{Conclusion}

The water resource available in the Couffo watershed upstream from the Lanta rainfall station varies according to the model and the considered period. The variations in rain of the considered periods are well simulated by the GR4J and HBV models. However, the accuracy of the results obtained has progressively decreased as the projection time becomes longer. The quantities of water estimated from the two models are quite large and can supply hydraulic infrastructures such as dikes or embankment dams. In this context, Gbédji-Kotovi clays can be valued. Conceptual models with few parameters such as those used in this research (by their robustness and their ease of use) appear the most likely to predict the short-term floods on the one hand, and to increase the prediction times compared with classical approaches to propagation on the other hand. They also make it possible to predict long-term low flows and to predetermine rainfall, with the joint use of a stochastic rain generator. Their importance is thus established in the detection of impacts on flows due to development or changes in land use and the dimensioning of flood capping and/or low-flow reservoirs and their management. Thus, other methods are needed to evaluate the hydrological impacts of climate change on floods in this watershed.

\section{Conflicts of Interest}

The authors declare no conflicts of interest regarding the publication of this paper.

\section{References}

[1] Alonso, E. (2002) Petits barrages, recommandations pour la conception, la réalisation et lesuivi (chapitre IV, Barrages en remblai); Comité Français des Grands Barrages. Editions CEMAGREF, 68-70. 
[2] Mounou, S.K.I., Codo, F. and Zevounou, C. (2017) Characterization with Geotechnical Testings of the Clay Sediments of Gbédji-Kotovi in Benin. International Journal of Scientific and Engineering Research, 8, 825-834.

[3] Mounou, S.K.I., Codo, F. and Zevounou, C. (2018) Analysis of Permeabilities of the Clayey Sediments of Gbédji-Kotovi Village in Benin for Its Valorization in the Construction of Dikes. Journal of Applied Sciences Research, 14, 45-56.

[4] Iheta, B., et al. (1982) Rapport sur les recherches géologiques d'argiles dans la zone du Bassin Sédimentaire côtier du Bénin, Programme des Nations Unies pour le Développement; Projet: Recherches minières au Bénin BEN/81/008.

[5] Sagbo, E. (2015) Characterization of Clay of the Benin Used in Ruminale Feeding. Complete Determination of the Smectites Contained in These Clays. Journal of Environmental Protection, 6, 1322-1336. https://doi.org/10.4236/jep.2015.611115

[6] Obada, E., Alamou, A.E. and Afouda, A. (2016) Evaluation des Performances de Neuf (09) Modèles Hydrologiques Pluie-débit Globaux sur le Bassin de la Mékrou à L'exutoire de Kompongou (Bénin). European Journal of Scientific Research, 140, 411-424.

[7] Azonsi, F., et al. (2008) Atlas hydrographique du Bénin, Système d'Information sur l'hydrographie. $18 \mathrm{p}$.

[8] Le Barbé, L., Alé, G., Millet, B., Texier, H., Borelt, Y. and Gualde, R. (1993) Les ressources en eaux superficielles de la république du Bénin. Éditions de l'ORSTOM, 441-413, 309-316.

[9] Amoussou, E., Camberlin, P. and Mahé, G. (2012) Impact de la variabilité climatique et du barrage Nangbéto sur l'hydrologie du système Mono-Couffo (Afrique de l'Ouest). Hydrological Sciences Journal, 57, 1-13. https://doi.org/10.1080/02626667.2011.643799

[10] Seibert, J. (2011) Introduction to Hydrological Modelling and the HBV Model How Do We See Reality? How Does a Hydrologist See Reality? System and Model.

[11] Perrin, C., Michel, C. and Andréassian, V. (2007) Modèles hydrologiques du Génie Rural (GR). 1-16, Cemagref.

[12] Lindström, G., Johansson, B., Persson, M., Gardelin, M. and Bergström, S. (1997) Development and Test of the Distributed HBV-96 Hydrological Model. Journal of Hydrology, 201, 272-288. https://doi.org/10.1016/S0022-1694(97)00041-3

[13] Ouachani, R., Bargaoui, Z. and Ouarda, T. (2007) Integration of a Kalman Filter in the HBV Hydrological Model for Runoff Forecasting. Hydrological Sciences Journal, 52, 318-337. https://doi.org/10.1623/hysj.52.2.318

[14] Collins, W.J. and Bellouin, M. (2008) Evaluation of the HadGEM2 Model. http://www.metoffice.gov.uk

[15] Gudmundsson, L. (2016) Statistical Transformation for Post-Processing Climate Model Output, R Package "qmap".

[16] Amoussou, E., Oyédé, L.M. and Boko, M. (2006) Variabilité pluvio-hydrologique et production agricole dans le bassin du Couffo au Bénin (Afrique de l'ouest). In: Risques liés au temps et au climat, Acte de Colloque AIC, Epernay, 67-72.

[17] Zevounou, C., Zannou, A. and Dahodo, M. (2017) Contribution à la réévaluation des ressources en eau de surface du Bénin par une analyse des séries hydrométriques récentes. European Journal of Scientific Research, 147, 80-86.

[18] Badjana, H.M., Hounkpè, K., Wala, K., Batawila, K., Kpagana, K. and Edjamé, K.S. (2014) Analyse de la variabilité temporelle et spatiale des séries climatiques du Nord du Togo entre 1960 et 2010. European Scientific Journal, 10, 257-275. 
[19] Vissin, E.W. (2007) Impact de la variabilité climatique et de la dynamique des états de surface sur les écoulements du bassin béninois du fleuve Niger. Thèse de doctorat, Université de Bourgogne, Dijon, $311 \mathrm{p}$.

[20] Mertz, O., Mbow, C., Reenberg, A. and Diouf, A. (2009) Farmers' Perceptions of Climate Change and Agricultural Adaptation Strategies in Rural Sahel. Environmental Management, 43, 804-816. https://doi.org/10.1007/s00267-008-9197-0

[21] Gnanglè, P.C., Glèlè-Kakaï, R.L., Assogbadjo, A.E., Vodounon, S., Yabi, J.A. and Sokpon, N. (2011) Tendances climatiques passées, modélisation, perceptions et adaptations locales au Bénin. Climatologie, 8, 26-40. https://doi.org/10.4267/climatologie.259

[22] Katé, S., Azontondé, A.H., Dagbenonbakin, G.D. and Sinsin, B. (2016) Effets des changements climatiques et des modes de gestion sur la fertilité des sols dans la commune de Banikoara au nord-ouest du Benin. International Journal of Biological and Chemical Sciences, 10, 120-133. https://doi.org/10.4314/ijbcs.v10i1.9

[23] Yabi, I. and Afouda, F. (2012) Extreme Rainfall Years in Benin (West Africa). Quaternary International, 262, 39-43. https://doi.org/10.1016/j.quaint.2010.12.010

[24] Sintondji, L.O., Awoye, H.R. and Agbossou, K.E. (2008) Modélisation du bilan hydrologique du bassin versant du Klou au Centre-Bénin: Contribution à la gestion durable des ressources en eau. Bulletin de la Recherche Agronomique du Bénin, 59, $35-48$. 